\title{
Determinants of Foreign Direct Investment in Pakistan
}

\author{
Syed Ali Mohiuddin \\ Muhammad Abdus Salam
}

\begin{abstract}
Foreign Direct Investment (FDI) is an investment in which investor from some other country invest in an enterprise of a different economy and the purpose of investment is to serve the business interests of the investor in that economy. Overseas investors always inclined towards those countries which assist them in terms of both infrastructure and encouraging policies for investments. Solid policies from the host country also circulate foreign investment into accurate areas where they are excessively desirable. Another reason of FDI flows from developed countries to developing countries is their comparatively young and inexpensive men-power. Foreign Direct Investment is playing key role in the development of any country's economy and especially in developing countries like Pakistan. The study was to statistically analyze the determinants of FDI inflows in Pakistan. The study covered data of macro level indicators during the period from FY 1973-74 to FY 2007-08 which would help in identifying determinants of FDI inflows in Pakistan.
\end{abstract}

Keywords: Foreign Direct Investment, Developing Countries, Investments, Development.

\section{Introduction}

\subsection{Background Of The Study}

Every country in the world realizes the importance of FDI including Developed countries as well as Developing countries. Emerging markets and developing countries are in need of funds and resources to continue their expansion and progress for which they offer better returns. While financier in the developed countries, invest their capital in Developing countries on the expectation of lofty profits. So this movement of wealth is advantageous and healthy for both of them. It is pointed out that return on the investment is on the higher side while the per capita GDP is on the lower level i.e. deprived host country suggests that these countries gaining low per capita GDP are appropriate targets for high return bound FDI.

Overseas investors always inclined towards those countries which assist them in terms of both infrastructure and encouraging policies for investments. Solid policies from the host country also circulate foreign investment into accurate areas where they are excessively desirable. In recent years, economic activity has been eminent by a notable increase in the global scope of trade. Another reason of FDI flows from developed countries to developing countries is their comparatively young and inexpensive men-power.

\footnotetext{
*Syed Ali Mohiuddin is an MS student at SZABIST Karachi, sam_ideaman@hotmail.com ${ }^{* *}$ Muhammad Abdus Salam is Deputy Director, Statistics and Warehouse Dept. SBP, Karachi abdussalamsbp@gmail.com
}

Journal of Independent Studies and Research - MSSE

Volume $9 \quad$ Number 1 January 2011 117 
After reaching at highest peak in 2000 , global FDI flows declined dramatically in subsequent years. In 2003, the United Nations Conference on Trade and Development (UNCTAD) 1 report showed terrible decrease in FDI inflow by a further $17.5 \%$ than the previous year. In value terms, global FDI inflows in 2003 were about USD 560 billion, 40 per cent of the USD 1,388 billion recorded in 2000. However, due to further cross border Mergers and Acquisitions (MandAs), higher economic growth worldwide and improved profitability among companies, the FDI situation in 2004 had shown prominent improvements and in 2006 and 2007, made new heights of 1411 and 1833 Billion \$ (UNCTAD, 2008).

World Investment Report (2004 and 2005) has shown the remarkable shift in FDI character towards services. In 1970, for example, services FDI accounted for a quarter of global FDI stock. In 1990, the share increased to about half, while in 2002, the share of services FDI to global stock rose to about 60 per cent. The dramatic increase in the shares of FDI (and trade) in services plus rapid changes in services related technology is forcing international agencies (like the United Nations) to reconsider the definition of services.

\subsection{Problem Statement}

Foreign Direct Investment is playing a key role in the development of any country's economy, especially in developing countries like Pakistan. The research problem behind this study was to statistically analyze the current determinants of FDI inflow in Pakistan.

\subsection{Objectives of the Study}

The objectives of the study are

- To empirically identify the current determinants of FDI inflow in Pakistan.

- To test their significance.

\subsection{VARIABLES}

Following variables were analyzed contributing in FDI inflows which were identified through literature survey.
a. Real GDP
b. Interest Rate
c. Exchange Rate
d. Infrastructure
e. Openness
f. Price

\subsection{Scope of the Study}

The study covered data of macro level indicators during the period from FY 1979-80 to FY 2007-08 which would help in identifying determinants of FDI inflows in Pakistan. 


\subsection{Research Methodology}

\section{Research Design:}

The research was quantitative in nature and for that researcher collected secondary data from different sources including State Bank of Pakistan, Federal Bureau of Statistics and National Highway Authority. Hence data was analyzed to find out significant determinants of FDI inflows in Pakistan.

\section{Sample:}

A sample of 35 years data from FY 1974-75 to FY 2007-08 was used to identify and analyze the significance of these determinants.

\section{Statistical Tools:}

Time Series analysis was used to find major contributing factors in recent FDI inflows in Pakistan through the software E-views.

\section{MODEL}

$F D I=f(R G D P, I R, E R, I S, O P E N, P)$

Where,

$\begin{array}{ll}\mathrm{FDI}= & \text { Foreign Direct Investment } \\ \mathrm{RGDP}= & \text { Real GDP } \\ \mathrm{IR}= & \text { Interest Rate } \\ \mathrm{ER}= & \text { Exchange Rate } \\ \mathrm{IS}= & \text { Infrastructure } \\ \mathrm{OPEN}= & \text { Openness } \\ \mathrm{P}= & \text { Price }\end{array}$

\section{Literature Review}

The theory of FDI is a "logical intersection" of three distinct theories: the theory of international capital markets, which explains the financing and risk-sharing arrangements, the theory of the firm, which describes the location of headquarters, management, and input utilization; and trade theory, which describes location of production and destination of sales (Casson, 1990). Determinants of FDI are different from sectors to sectors like for agriculture, services and financial sectors and from country to country. Surplus labor due to rise in unemployment, retrenchments, enticing voluntary retirements, compulsory retirements, the decline in bargaining power of labor are some of the determinants of FDI in India (Nayek, 2003). 
There are some studies available in the case of Pakistan in which researchers identified the determinants and significance of Foreign Direct Investment (FDI) in Pakistan. Pakistan government has started reforms in the 1980s in its economic policies and gradually started to liberalize its trade and investment regime by giving tax exemptions, credit facilities and generous tariff reductions to foreign investors. In 1990s, the government further eased its policies in investments in agriculture, telecommunication and energy sectors but due to inconsistent policies and political instability, the level of FDI remained low compared to other developing countries (Khan, 1999).

Pakistan received reasonably higher amount of FDI over the last two decades due to market sloping strategies, favorable situation for investment and affirmed the private sector as the engine of economic growth (Atique, 2008). Many developing countries took advantage by the forein investments and financial support in improving the ability of undersized investors to use financial services, attract investments from the globe and construct financial infrastructure. Attracting foreign investments help in reducing

gap between the need of investment and local savings (Shabbir, 1992). Recent studies showed the impact of particular policy variables for FDI in host countries and focused on policy restructuring in developing countries in the form of determinants of FDI inflows (Gastanaga et al, 1998). Inflation directly affects the level of FDI which when under control attracts more FDI in host country or in other region. Low inflation rate highlight to the investors that monetary policy is being handled as per defined parameters and investment returns would meet investors' expectation (Agim Kukeli, 2007).

\subsection{Overview of Foreign Direct Investment}

Direct investment is an international investment in an entity of one economy for long term interests from another country. Direct investments cover all transactions from opening transaction and all succeeding transactions. In a direct investment, foreign investor owns $10 \%$ or more of the ordinary share in an enterprise. Holding of less than $10 \%$ of the equity termed as foreign private investment. In direct investment, investor has lasting interest (long-term relationship) in the entity and influence on the management of enterprise.

More and more countries depend on FDI instead of loans in economic growth and that is why the world has seen drastic growth in developing economies with continuous foreign investment. Also the movement of funds from developed countries to the developing countries has increased significantly in last two decades.

FDI plays a vital role in the overall economic and social development of the host country including infrastructural condition, scope of technological development, and living standard of the general public. FDI can also be supportive in improving host country's educational system and to set up mass level technical educational programs as any foreign investment

needs more and more skilled labor. This will help society to educate their deprived sections. Host developing countries can also start to improve their healthcare problems with the help of FDI which is often provided by Non-Governmental Organizations. 
FDI is a long term commitment and has positive developmental role in general. FDI contains a package of capital, technology management and market access and attracted by those sectors of an economy that have comparative advantage. Initially, all the FDI flows to the countries of newly industrialized economies but then it has changed its direction to other countries of Asia and Pacific region. FDI inflows in Pakistan are comparatively small and in few sectors only, typically in Power and Energy sectors and lately in the telecommunication sector. Till late 90 's, Pakistan accounted for only $0.2 \%$ of world FDI and below 1\% of the FDI of developing countries despite its policies to attract FDI, liberizing the economy and elimination of obstacles to international investors, but Pakistan's performance was not better than average.

\subsection{Investment Policies and Foreign Investment in Pakistan}

Government of Pakistan is encouraging FDI by making favorable policies and offering various incentives to international investors. Here we can look at a glance on investment policies in different sectors of Pakistan. For manufacturing/industrial sector, international investors are allowed to hold $100 \%$ of the equity without government permission. Even there is no need of any NOC from the provincial governments for setting up of these projects. All manufacturing/industrial units except the manufacturing of arms, ammunition and heavy explosives comes under this sector. For non-manufacturing/industrial sector, international investors are allowed to hold $100 \%$ of the equity on repatriable basis. Services sector, infrastructure, social sector, tourism, housing and construction, information technology, portfolio investment, all comes under this sector.

Currently many foreign companies are working in Pakistan in different sectors like food and beverages, pharmaceuticals, insurance and banking, chemicals, automotive assembly, oil and gas exploration and marketing, power generation etc.

Compared with the opportunities and economic fundamentals of the country, Pakistan's share is negligible of the total FDI made globally. During 1990's Pakistan has received highest FDI of US\$ 1 billion in financial year 1995-96 and then there was a down ward trend due to several reasons including nuclear tests and economic restrictions. After massive incentives and favorable policies to global community of investors, Pakistan touched the highest FDI inflow of US\$ 5 billion in financial year 2007-08. Now the trend is again declining due to recent economic crunch globally but the need is to take substantial measures to retain international investment in Pakistan. Pakistan was one of the few countries in the region which open their market for foreign investment in early 1990 's. Legal cover, benefits and incentives for investment is continuously provided by the government for foreign and Pakistani investment, hence it extended to new areas and sectors like telecommunication, information technology, information services and financial markets. Acts like Foreign Private Investment Act, (1976) and Protection of Economic Reforms Act, (1992) cover protection of foreign investors in Pakistan.

\section{Data Analysis and Findings}

To examine the characteristics of any long-run association between Foreign Direct Investment and the variables recommended in our model, we now continue to analyze 
whether the series are cointegrated, entailing that any variations from any long run equilibrium association that exists between them will themselves be stationary. Except series are cointegrated, there is no equilibrium association between variables and conclusion is inadequate.

\subsection{Unit Root Test}

To test for cointegration, we first verify that all variables that we anticipate to be cointegrated with Foreign Direct Investment are each individually (1).In this section we perform unit root tests for stationarity on the levels and the first differences of all variables. The Augmented Dickey Fuller Test shows the existence of unit roots, and hence nonstationary in first difference of some of the variables (rgdp, $p$, fdi). However by taking log of these variables, all variables are stationary at first differences. Hence we conclude that these variables are integrated of order 1.

\subsection{Estimation of a Cointegrating Vector}

In order to identify a cointegration relation among the variables, we employ the Johansen cointegration test. We first specify the relevant order of lags of the vector autoregressions (VAR) model. Since the sample size is relatively small, we select 1 for the order of the VAR. The Max Eigenvalue test suggest $r=2$ at 1 per cent significance level. Therefore, our annual data appear to support the proposition that in Pakistan there exist a longrun relation between Foreign Direct Investment and its determinants.

\subsection{Vector Error Correction Estimates}

The VECM model is proposed to describe the short term dynamics of Foreign Direct Investment in Pakistan. This type of model explicates the instant short-term adjustments in dependent variable by means of deviations from a specific equilibrium association between the dependent variable and the explanatory variables.

The results of estimation of the ECMs are shown in Table 4.The lags of the explanatory variables are chosen in according to Akaike Information Criteria and indicate lags upto two periods.

\subsection{Interpretation of Empirical Results}

The analysis of the results suggest that if LFDI > 4.571 LRGDP - 2.013 LP + 0.109 OPEN - 0.00000375 IS + 0.105 DR + 0.048 EXR

Then FDI falls and/or Real GDP, Exchange Rate, Openness and Discount Rate increase to restore the equilibrium. In FDI each year 5.4\% of the discrepancy from long-run equilibrium is corrected. This adjustment, although slow and statistically insignificant but the sign are as per requirement. As indicated all the variables except Infrastructure and Interest Rate have the expected signs. Thus our results give some evidence that reducing Price level would positively affect the FDI. Moreover, the coefficient of exchange rate and Real GDP are positive implying 
that when rupee appreciates and Real GDP increases, FDI increases as investors see it as a good sign for the economy and expect high returns.

\section{Conclusion}

Pakistan is an important country of the world due to its geographical location. Over thousand kilometer of coastline with Arabian Sea made it a gate way to trade with Central Asia, Middle East and other markets of the world. Its borders with Afghanistan, Iran, China and India increase its strategic value. Pakistan is seventh most populous country in the world and enrich with resources. Financial system, securities and money markets are well developed give full protection to foreign and local investors. With a big market of buyers and sellers, Pakistan has potential to attract more FDI from the globe. Policy makers should strongly make attempts to magnetize more FDI. Political strength and reasonable law and order situation are also crucial to draw the attention of international investors. Growth in information and communication technologies, advancement in logistics, low cost labor is also some of the key points to attract FDI. Financial concessions are also part of the respective policies for attracting more and more investments.

The study uses the Cointegration and error-correction techniques to identify the variables in explaining the FDI in Pakistan. Our results show that the variables are exogenous. The results showed a positive relationship between FDI and Exchange Rate. The reason for this may be that an increase in Exchange Rate increases the relative buying power of home country in the host country. The results also showed positive relationship between Real GDP and FDI. Means investors are attracted towards those economies with high GDP.

\section{Area for Further Research}

A cross country study of developing countries with rich data is recommended to further investigate the determinants of Foreign Direct Investment.

\section{Limitations of the Study}

The analysis is based on the data gathered for the year 1974-2008. Data size is small but due to the lack of time and data available, we were restricted. Our result is reliable under these limitations. For better and comprehensive results on FDI, we need large sample size. 


\section{References}

Agim Kukeli (2007), International Business and Economics Research Journal

Atique Zeeshan, Ahmad Mohsin Hasnain and Azhar Usman (ca. 2005) "THE IMPACT OF FDI ON ECONOMIC GROWTH UNDER FOREIGN TRADE REGIMES: A CASE STUDY OF PAKISTAN" Pakistan Institute of Development Economics

Casson, M. 1990. "The Theory of Foreign Direct Investment." In P. Buckley, ed., International Investment. Aldershot, England: Edward Elgar Publishing Ltd.: 244-73

Gastanaga, et al (1998). "Host Country Reforms and FDI Inflows: How Much Difference Do They Make?" World Development.

Khan, Ashfaque H. and Yun-Hwan Kim (1999), EDRC Report Series No. 66.

Nayek, Birendra Kumar and Dev Surya (2003) "Low Bargaining Power of Labour attracts FDI in India" Retrieved April 26, 2009, from papers.ssrn.com

Shabbir, et al (1992). "The Effects of Foreign Private Investment on Economic Growth in Pakistan". Pakistan Development Review. Islamabad: Pakistan Institute of Development Economics.

United Nations Conference on Trade and Development (UNCTAD) Report 2008. 